this place. We are building our church, there is a meeting of the building committee at my house at 3 o'clock, and I want you to come there and take the chairmanship of the committee." And when the time came $\mathrm{Mr}$. S. was there and he never gave the church or community any more trouble.

When Mr. Clarke died the official memoir of him was written by the late Michael Hare, who was a devoted friend of his. But the best of all the memoirs was written by Henry Clay Dean. Dean was devotedly attached to Father Clarke. He was the only preacher of the Iowa Methodist church to whose leadership and power the great orator deferred, and he poured out the warmth of his feelings in an eloquent tribute worthy of Samuel Clarke and worthy of Henry Clay Dean at his best of heart and brain and pen.

\title{
THE DES MOINES RIVER LAND GRANT.
}

BY COLONEL C. H. GATCH.

[SECOND PAPER.]

It should have been previously stated that the Des Moines Navigation \& Railroad Company became incorporated as an Iowa corporation under articles filed May I9, I854, and that the incorporators were Edwin C. Litchfield, Porter Kibbee, Orville Clark, B. R. Whitmore, Henry O'Reilly, A. Hunt, Elisha C. Litchfield, Henry Ten Eyck, John Stryker, Nelson B. Stewart and E. B. Litchfield:

May I 5, I 856, Congress granted to the State of Iowa, for the construction of four railroads from the Mississippi to the Missouri river, every alternate section of land designated by odd numbers, for six sections in width on each side of each of the roads, with the usual provision for indemnity selections within designated limits in case any of the granted sections had been previously disposed of. The grant was subject to 
the following proviso, which it will hereafter be seen contributed very materially to the legal questions and complications that were to follow: "That any and all lands heretoforereserved to the United States, by any act of Congress, or in any other manner by competent authority, for the purpose of aiding. in any object of internal improvement, or for any other purpose whatever, be and the same are hereby reserved to the United States from the operation of this act." The line of each of the railroads thus provided for would necessarily intersect the grant of lands for the improvement of the Des Moines River, provided it extended to the northern limit of the State. On the day of the passage of this act the Commissioner of the General Land Office directed the officers of the local land. offices in Iowa to withhold the lands covered by the grant from sale or location until further orders. July i 4, 1856, the General Assembly of Iowa accepted the grant.

The matter of the extent of the river grant having again been brought before the Secretary of the Interior, it was by him reterred to the Attorney General, Hon. Caleb Cushing, who, May 29, 1856 , rendered an opinion, the substance of which is stated in this sentence:

"I have hesitated much on the question whether that be not the true view of: the subject (to limit the grant to the Raccoon Fork) but, for reasons already suggested, have come to the conclusion on the whole, to advise you to stand on the last decision, (Secretary Stuart's) which gives to the State the lands along the course of the Des Moines, up to the northern boundary of the State.

$\mathrm{U}_{\mathrm{P}}$ to this time the State had been claiming the lands on each side of the river from its mouth to the northern limits of the Territory, which was much further north than the northern line of the State as fixed at the time of its admission into the Union. In view of this claim to lands, which were then within the limits of the Territory of Minnesota, the Attorney General in his communication containing the opinion referred to, advised as follows: "I advise, therefore, that you propose to. the State of Iowa, and its assigns, to acquiesce in and accept the decision of Mr. Stuart as final, and to approve selections accordingly; provided, the State and its assigns will themselves. agree to acquiesce in and accept that decision as final." He 
- further advised that if the State refused to accept the grant upon this condition that the Secretary of the Interior should refuse absolutely to approve any more selections above the Raccoon Fork. Acting upon this advice, the Secretary wrote the Commissioner of the General Land Office June 9, I 856 , as follows :

"In the subsequent action upon selections not yet approved, I have concluded to be governed by the advice of the Attorney General, as contained in the paragraph near the close of his opinion, beginning with the words, 'I advise, therefore, that you propose to the State of Iowa and its assigns,' and ending with 'You can with safety award to them the residue of the claim up to the northern boundary of the State.' In the certificates of approval hereafter prepared for my signature on any list submitted, the fact should be stated that the approval being based upon the prior action of the department and upon the ground that the grant is to be confined to the northern boundary of the State of Iowa, the acceptance by the State and its assigns would be considered an acquiescence on their part in this limit, and an abandonment of all claim beyond it, as it is upon this basis alone I . can feel justified in yielding my assent to the claim preferred."

July I6, I856, W. C. Johnson, the then president of the Navigation Company, having applied to the Secretary of the Interior for the certification of additional lands, the Secretary, in a letter to the Commissioner of the General Land Offiee, directed that action be suspended until the assent of the proper authorities was obtained to the conditions mentioned in - the foregoing opinion of Attorney General Cushing.

January I, i 857 , Commissioner Manning made his report to the General Assembly in which he refers to the fact that the affairs of the Improvement are in the hands of a joint committee of investigation, and among other things says: "The State of Iowa, through its Board of Public Works, prosecuted the Improvement about six years, up to June 9,1854 , and during this period expended about $\$ 475$,000." And further "The character and quality of the work upon the lock walls is believed to be fully equal in all respects to that heretofore constructed by the state, which condition in the original contract in that respect is believed to be complied with."

The report shows that on December I, I 856, the Navigation - Company had paid out and expended, under its contract with the State, for purposes recognized as falling within the terms 
of the contract, $\$ 366,711.26$; and charges the Navigation Company with two lists of lands theretofore sold to it by the officers of the Improvement, one list comprising 88,853.19. acres, and the other $116,636.04$ acres, amounting, at $\$ 1.25$ per acre, to $\$ 256.861 .53$; thus leaving a balance at that time due the Navigation Company of $\$ 109,849.73$. An adjust-. ment between the State and the Navigation Company made December 24, 1856, is referred to in the report, in and by which it was agreed and settled that there was then due from the State to the Navigation Company, after eliminating certain. matters of difference between the Commissioner and the Company, a balance of $\$ 40,369.04$; of which among other things it is said: "The present adjustment has been mutual-. ly entered into with a full view of all the embarrassments and difficulties heretofore and at present encountered, and more especially to hasten and insure the immediate progress and early completion of the work." And as showing the fairness of the adjustment it is further said:

"The manifestation of the President of the company in making this arrangement appears to be quite equitable, and it is due from me to admit that his efforts in behalf of this adjustment have been of the most laudable character. The concessions herein made by the Company to the State are agreed to by me as highly creditable to the Company and equitable to the State. It is but right to regard it as an evidence of their good faith to perform this agreement."

By taking the balance of $\$ 40,369$ allowed the Company in the adjustment from the balance of $\$ 109,849$ due it according to the Commissioners' report, it will be seen that the Company made a concession of nearly $\$ 70,000$ in the adjustment.

In the report of J. C. Lockwood, Register of the Improve- . ment, of January I, I857, it is said:

"From an examination of the lists of lands approved by the general government as coming within the Des Moines River Grant, and plats of those remaining unsold, it would appear that there were $266,107.13$ acres undisposed of when the . sales ceased per act of the Legislature, and of these only about 55,000 acres were situated below Fort Des Moines. I also find from the records of my office that there were certified of the above lands to the Des Moines Navigation \& Railroad Company, by the Register, on the requisition of Commissioner Bonney, and the estimate of the acting engineer on the $I_{4}$ th of May, I 855, 88,853.I9 acres. On the 6 th of May, 1856, I received from Commissioner McKay the following requisition and estimate of the acting engineer, and on their receipt, certified to. 
the Des Moines Navigation \& Railroad Company, I $15,726.16$ acres......After deducting the amounis of the above certificates, there now remains undisposed of $61,527.78$. There have been about thirteen hundred certificates issued by former Registers, to persons who purchased Des Moines river lands from the State, between the 12 th of October, 1852 , and December, 1853 , and for which no patents have been executed."

January I, I 858, Commissioner Manning made his annual report to the Governor, in which he says the amount of expenditures by the Company, as claimed by it, up to December 1,1856 , was $\$ 366,7 \mathrm{I} \mathrm{I} .26$, and referring to the adjustment of December 24, I 856 , says: "This adjustment with said Company was regarded by the Commissioner as having ascertained and fixed the amount thus expended by said Company on the improvement under their contract, with the .State," and following this admits the amount expended for debts, liabilities, improvement, engineering, etc., up to December I, 1856, "by said Company upon said Improvement" to have been $\$ 256,861.53$, and that there was to be added to that sum, expended from December I, I856, to December I, I857, the further sum of $\$ 77,193.70$, making the total less 15 per cent. of the last mentioned sum "reserved by the State till final .completion," \$322,436. I8.

February 16, 1858, Governor Lowe sent to the general assembly a special message in reference to the Improvément, in which he stated that the entire grant of the Des Moines River lands embraced within the limits of the State, as accurately as could be ascertained, was 853,430 acres, of which amount the General Government had then only certified to the State $593,430.89$ acres; and that of this last amount up to the date of the contract between the State and the Navigation Company, July 9, I 854, the Board of Public Works and State Commissioner had sold and disposed of $327,314.53$ acres, the receipts for which were $\$ 410,750.26$; that since June 9, I 854 , there had been certified to the Des Moines Navigation \& Railroad Company, at \$1.25 per acre, 205,489.23 acres, and that there was a requisition in dispute for 24,000 acres more, leaving 37,537 acres of the land certified by the General Government to the State undisposed of ; that the Company claimed to 
have expended, subsequent to June 9 , I 854 , on account of the Improvement, including incidental expenses, $\$ 544,547.84$, and that the State Commissioner reduced this amount to $\$ 270,005$.84. The message concluded with the suggestion that the "difference in the estimate of expenditures" might be "amicably adjusted" by the "appointment of a competent commissioner for that purpose, or the raising of a joint committee of the two houses, to settle all points of difference between the parties, and dissolve the contract if deemed expedient."

On the 22nd of March, I858, the General Assembly passed an act making a grant in the following terms to the Keokuk, Fort Des Moines \& Minnesota R. R. Company:

"All lands and compensation which may be given in extension or in lieu of any portion thereof by the General Government, and also all stone, timber and other material turned over to the State by the Des Moines.Navigation \& Railroad Company in settlement with the State of Iowa,......... to aid in the construction of a railroad from the city of Keokuk at the mouth of the Des Moines River up and along the valley of said river by way of the city of Des Moines to the northern line of the State,.........excepting all the land belonging to said grant heretofore sold by the State of Iowa or which miy hereafter be conveyed to the Des Moines Navigation \& Railroad Company, by virtue of a settlement now pending between the State and said Company,.........this grant to become operative as soon as Congress shall assent to or permit a diversion, or the title thereto shall become vested in the State so as to be subject to grant."

On the same day the State appointed Charles Mason its agent to procure the further certification of lands to the State under the grant. On the sane day also the General Assembly passed a joint resolution containing a proposition for settlement with the Navigation Company, and another instructing the Governor to enjoin the Company in the event of its failure to accept the terms of the compromise offered in the preceding joint resolution from

" Proceeding further with the improvement of the Des Moines River and to take such other means as he and his legal advisers may think best to protect the interests of the State in any dispute that may arise between the State and the Des Moines Navigation \& Railroad Company in consequence of such injunction or any other process or proceedings that may be necessary against said Company."

And, further, on the same day, passed an act disposing of all the remaining Des Moines river lands by a grant of the same 
to the Keokuk, Fort Des Moines \& Minnesota Railroad Company, to aid in the construction of a railroad from Keokuk to the northern line of the State. April 15, 1858 , the Company, by vote of its Board of Directors, accepted the terms of compromise proposed by the State. April 28, I 858, Governor Lowe certified to the President of the United States, that the Company had expended money to the amount of $\$ 332,634.04$ in work on the Improvement, for which the State was about to convey lands to it amounting in the aggregate to $266,107.23$ acres. May 3, I 858 , the remainder of the lands theretofore certified to the State under the grant, lying north of the Raccoon Fork, were certified by the Register of the State Land Office to the Navigation Company, pursuant to the joint resolution of March 22.

May 3, 1858, the State of Iowa, by Governor Lowe, executed fourteen deeds or patents to the Navigation Company, conveying by particular description, the lands to which the Company was entitled under the resolution of compromise; and May I8, 1858, a general deed, conveying the same and any previously omitted lands, by general description.

January I, 1859, Commisșioner Manning filed with the Governor his report, in which he stated that the Navigation Company had paid to him as Commissioner the twenty thousand dollars required to be paid by the terms of the joint resolution of compromise. And January 9, 1860, Governor Lowe submitted to the Legislature his annual message, in which he said: "The settlement made at the last session of the Legislature with the Des! Moines Navigation \& Railroad Company has been duly carried out according to the terms expressed."

While few Iowa people do not know in a general way of the troubles between the State and the Navigation Company about the "River Lands," probably fewer still know much, if anything, of the particular causes that gave rise to it, and I have purposely passed over such of them as seemed most deserving of notice, intending to return and by making them matter of separate and special mention, account more intelligibly for a 
controversy about which however much has been known so much seems not to have been known. On the one hand the Company has been charged with having "robbed" the State of hundreds of thousands of acres of land, while on the other hand the State has been charged with having attempted to rob the Company of about a million more acres by arbitrarily putting an end to the contract under which it claimed it was. entitled to buy them at $\$ 1.25$ an acre in work on the Improvement. As will hereafter be seen the Company, on the one hand, paid the contract price for all the land it received, and, on the other, the State could not have made title to the remaining lands if the Company had actually earned them in work on the. Improvement to the required amount, the grant, after the repudiation of the contract by the State, having been held by the Supreme Court of the United States not to embrace them. Had both the State and Company acquiesced in Attorney General Cushing's proposed compromise, making the northern boundary line of the State instead of the source of the Des Moines River in Minnesota the northern limit of the grant, there might not have been occasion for any such charges or indeed any such thing as the "Des Moines River Land: troubles." Which party, if either, was to blame in this particular contention, is a matter about which there is room for honest difference of opinion upon the statements to be presently referred to.

W. C. Johnson, the then president of the Navigation Company in his report as such to the Governor November 15 , 1856 , -says that as early as May, I 855 , "nearly half the work . was prepared for letting and was put under contract." And further that.

"At this point information was received that the General Assembly had passed" an act in derogation of the title which had been agreed to be given to the Company, and requiring that no patents should issue to the Company, except with a derogatory clause inserted."

The following is the derogatory clause referred to :

"Nothing in this patent shall be construed into a warranty by the State against any claim or claims to said lands arising out of any pre-existing contract in relation to any lands, made or entered into by the State, or any of its agents, nor- 
as intended to interfere with any of the rights of any person or company, to any of said lands accruing by virtue of any law of this State, or any contract under the provisions of any of said laws."

Further on in his report, referring to the suspense in which the company was kept by reason of the uncertainty as to what should be finally held as to the extent of the grant, he says :

"But it was not until June that a decision was given, and then it was that the grant might be construed as extending to the nurth line of the State, provided the State should release the lands lying above. Thus matters bave stood until this time, the Government refusing to recognize the grant as extending beyond the north line of the State (cutting off about 300,000 acres of land) and refusing to recognize the grant as extending beyond the lands already approved to the State, except on the condition of the execution of a release of the balance. In this condition of the grant the Company felt that good faith towards the State required of it, a suspension of new work until the wishes of the State in the premises could be ascertained........ The Company bas expended in payment of State indebtedness and construction (exclusive of the salaries of its officers and office expenses) more than the sum of $\$ 360,914.14$, on account of which there have been certified to it by the Register and Commissioner of the Des Moines Improvement, two hundred and five thousand four hundred and eighty-nine and twenty-three onehundredths acres of land under its contract, leaving over a hundred thousand dollars due from the State and for which it is in arrears to the Company. To pay this would more than exhaust the balance of the lands, the title to which has, as yet, been transferred by the General Government to the State, excluding those which have been erroneously approved, and the entire balance of the grant is embarrassed by the refusal of the General Government to make more transfers to the State except on condition of a release of the lands north of the State line."

One Donald Mann presented a memorial to the General Assembly at its special session in 1856 , charging mismanagement and fraud on the Managing Directors and Executive Committee of the Navigation Company, particularly in the matter of alleged issues of apparently "paid up" stock, on which in fact only a small per cent. had been paid, on part only five per cent. and on part only twenty per cent., thereby, as was alleged, deceiving both "the public and individuals," and through failure to realize from payments on stock and a consequent want of funds with which to prosecute the same, retarding the work on the Improvement. Another memorial presented by him to Governor Grimes on the same subject was by the Governor laid before the General Assembly at its 
regular session in 1856 ; and the Governor's annual message submitted to the General Assembly at the commencement of the same session, referring to a request of President Johnson of the Navigation Company, and to the affairs of that Company generally, contained the following:

"I received on the 3rd day of last October from W. C. Johnson, Esq., president of the Des Moines River Improvement \& Navigation Company, a request that I would examine into the affairs of that Company; or cause them to be examined by a committee whom I might appoint, and proffering to pay all expenses that might be attendant thereon. Although the Governor of the State had no authority to appoint such a committee, yet the necessity for such an investigation was so great that I should bave exercised the power but from my inability to procure the services of the most desirable persons for the duty. It is due to the people of the State and to the members of the Des Moines River Improvement \& Navigation Company, that the rights and relations of the Company to the State should be definitely ascertained, and distinctly understood. To this end it is recommended that a commission be appointed, with power to administer oaths and to send for persons and papers, with instructions to inquire into all the transactions of former Commissioners and Registers of the Des Moines River Improvement; to report as to the character and validity of any contracts that may have been made between the State and persons or companies for the improvement of. the Des Moines river, and especially to, report with regard to the transactions of the Des Moines River Improvement \& Navigation Company.

"Until such investigation is made and report submitted, it is recommended that all action on the part of the State in connection with the Des Moines Improvement and the Des Moines River lands be suspended."

A joint investigating committee was accordingly appointed by the General Assembly and made its report to that body at the same session of $1856-7$. The following are extracts from their reports :

"Your committee are of the opinion that no legal contract was ever entered into by the State of Iowa with the Demoine Navigation \& Railroad Company.

(In this it will be seen hereafter the committee was mistaken, the Supreme Court having held otherwise.)

"By the terms of what is claimed to be the original contract, the whole Improvement was to be completed by the first of July, 1858 , and one-quarter of the work done annually. Now, according to the evidence thefore the Committee, it appears that there were expended by the Company up to the first of December, 1856 , a period of nearly two and a half years in actual construction, $\$ 185,957.44$, and in engineering and incidental expenses, $\$ 104,180.74$. Your Committee can find no reasonable excuse for the extraordinary sluggishness with which the work has baen prosecuted, compatible with an honest purpose of prosecuting the work to completion, for the sole consideration of receiving in payment therefor the lands granted by 
Congress, and the use and rents of the Improvement and water. Now, if the D: M. N. \& R. R. Co. had a bona fide capital actually on hand of nearly $\$ 1,000, \infty 00$, paid in for the prosecution of the work, as they ought to have according to the amount of stock issued, and had hitherto prosecuted the work with that vigor and energy which its importance demands, and which the people of the State had a right to expect, the condition of things would be very different; but as the work has been done, in the opinion of your committee, under contract without any validity in law, and if said contract had been valid, in no manner according to the spirit and meaning thereof, your committee are of the opinion that said company are justly and equitably entitled to a fair compensation for the work done by them; but are not entitled, unless the State so elect, to payment in lands at $\$ 1.25$. per acre, which are worth six or seven dollars per acre.

The committee were D. T. Brigham, W. F. Coolbaugh, Wm. G. Thompson, J. W. Jenkins, J. J. Matthews, on the part of the Senate, and D. Edmundson, B. F. Roberts, John H. Fry, Miles Jordan, David Doud, Jr, John E. Kurtz, and James Galbraith, on the part of the House.

Governor Grimes in his message to the General Assembly, January, 1858 , referring to this report of the joint committee, , said :

"From the report of the Joint Committee of the two houses of the last session. of the General Assembly, it would seem that the terms of this contract had never been complied with by the Company, but that it has been disregarded in its most essential particulars, whereby the purposes for which it was entered iffo have not been and will not be attained. If this be true, you may feel it to be your duty to rescind that contract, for the reasons stated in the report, and make other arrangements in relation to that munificent grant, now in danger of being frittered away without any useful result. The report above referred to also indicated that the Des Moines Navigation and Railroad Company have not only forfeited their charter by a failure to comply with the requirements of the statute, but they have engaged in practices calculated to deceive and defraud, upon a large scale, innocent and unsuspecting persons, both at home and abroad. If this be true, it may be thought a matter of sufficient public importance to justify you in directing the Attorney General to institute proceedings to vacate the charter of the Company, and thus prevent it from perpetrating any further wrongs under the authority of the laws of this State."

Commissioner Manning, from his report of January I, I857, about the same date it will be observed as that of the report of the Joint Legislative Committee from which the foregoing extract is taken, evidently did not agree with the Committee that the alleged unreasonable delay. on the part of the Company was a matter of which the State had any reason to complain. He said : 
"The policy heretofore adopted by the Company and approved by former Commissioners, of putting the entire line of improvement in progress at the same time, with a view to the simultaneous completion of the same, was, as has since been demonstrated, impracticable, from the fact that the country is yet new and but partially settled and improved, with only a limited supply of laborers in its vicinity. If the locality of this improvement was more convenient to the densely populated portions of the east, the case would be different. But when it is considered that it is one thousand miles distant from the seaboard, thereby rendering uncertain the procuring of the laborers necessary for its successful progress, then it becomes more apparent that the limited force at command should be employed so as to make the first section of the work available at an early day, whereby the citizens of the valley, as well as the Company, can derive some immediate benefit from the great expenditure upon the improvement. All past experience in like great internal improvements warrants me in this view of the subiect."

In the case of the State on the relation of Johnson, President of the Navigation Company, against the Commissioners of the Des Moines River Improvement, a mandamus proceeding to require the Commissioner of the Improvement to transfer and convey to the Company 89,000 acres of land claimed by the Company as having been earned under its contract, the Supreme Court of Iowa at its June Term, I857, in a decision not found in the printed reports, held, that the contract of June 9,1854 , was valid and that while the supplemental agreements, one of the same date, and the other of June 29, I 85.4, were originally invalid for want of the Governor's approval, the necessity of such approval had been waived by the repeated and express action of the executive and legislative departments of the government.

The writ of mandamus was denied for the reasons :

Ist. That it did not appear from the petition that the onequarter of the work required to be completed in each year had been so completed.

2nd. Because the proceeding was in effect for specific performance of the contract and the petition did not show either performance or readiness or willingness on the part of the Company to perform.

3 rd. Because from the petition and record it was doubtful whether the amount claimed or any amount was due on the contract and settlement with Manning. 
Commissioner Manning in a report made to the Governor, January I, 1858 , referring to this decision said:

"The Supreme Court dismissed the application for a writ of mandamus, for the reason, among others, that it did not show such a compliance upon the part of the Company with their contract as entitled them to a specific performance upon the part of the State; and the Company not choosing to amend their application and risk an issue of fact with the State upon the question of their performance the litigation was ended."

- There seems to have been a contention between the Company and the State as to their respective rights under the contract as affected by the greater or less extent of the grant, accordingly as the location of its northern boundary should be finally determined; the Company claiming to be entitled to all the land within the limits of the grant even though it should, at $\$ I .25$ per acre, exceed the estimated cost of the improvement- $\$ 1,300,000$-and, on the other hand, that it was not liable for more than $\$ 1.25$ per acre should the quantity of land within the grant prove to be less than the estimated quantity.

Commissioner Manning in his report already referred to, referring to this contention, said:

“The Company has agreed to pay and the State has agreed to take $\$ 1,300,000$ for the land, etc. The sum is fixed for the aggregate, the contract don't call for or contemplate any given or certain quantity of land, but is definite in other respects, insomuch that the Company get all that belongs to the grant after the date specified. Now, the Demoine Navigation \& Railroad Company repudiate and decline to pay the sum agreed upon for said 'grant' and this refusal has just been announced by the Company, and their policy disclosed. The fact is no longer disguised that the said Company now utterly refuse to acknowledge any liability whatever to the State to pay more than $\$ 1.25$ per acre for the land of the grant, and if the same exceed a certain amount, then they will or will not, as they please to elect."

Following which he further states, that he and General Clarke, the latter acting as agent for the Company, visited Washington with reference to the compromise proposed by Attorney General Cushing, and that when there Secretary Thompson proposed to "carry out the verdict of Cushing;" whereupon he, Manning, proposed to Clarke to "co-operate with the Company, and either accept or reject the Cushing opinion, leaving the Company to elect which course to adopt." 
The report proceeds:

"At this juncture of our proceedings the agent of the Company (General Clarke) required the Commissioner (Manning) to accept the lands, and the interpretation of the act as provided in Attorney General Cushing's opinion rendered in the case, and that upon the condition that the Commissioner or the State would release the Demoine Navigation \& Railroad Company upon their contract of $9^{\text {th }}$ June pro rata and to the same extent that the State and Company are required to relinquish to the General Government under Cushing's opinion, then upon that condition the Company would co-operate with the State, but upon no other or better terms. This proposition was rejected by the Commissioner as not intended in the contract between the Company and the State, and thus the case now stands."

\section{It is further said :}

"The release they (the Company) demand of the State, involves a question of at least $\$ 400,000$ importance to the State, and is, in the opinion of the Commissioners, the gravest and most vital question that has ever arisen between the Des Moines Navigation and Railroad Company and the State."

Resuming the chronological order of statement where it was interrupted by the foregoing somewhat lengthy digression :

March 29, I 859, Mr. Thompson, Secretary of the Interior, wrote the Commissioner of the General Land Office transmitting a copy of the opinion of Attorney General Black, holding that the grant did not extend above the Raccoon Fork, and concluded his letter as follows :

"In the view of the Attorney General as thus expressed, I fully concur, and it therefore only remains for me to inform you that no further action can be taken in this department or in your office which will recognize the grant as extending above the Raccoon Fork of the Des Moines River."

At the December term, I 859, of the Supreme Court of the United States, in the case of the Dubuque \& Pacific Railroad Co. vs. Litchfield, reported in 23 Howard, 65, it was held that the grant did not extend above the Raccoon Fork, and that the act of the Secretary of the Interior in certifying lands to the State under it were void and conveyed no title.

In consequence of this decision Mr. Wilson, Commissioner of the General Land Office, caused the following notice, dated May I 8, I860, to be posted in the local land offices in Iowa :

"Notice is hereby given that the lands along the Des Moines river in Iowa and within the claimed limits of the Des Moines grant in that State above the mouth of the Raccoon Fork of said river, which bave been reserved from sale heretofore 


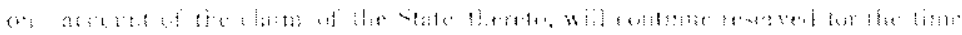

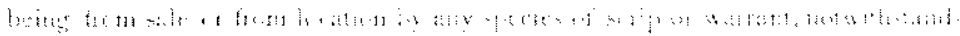

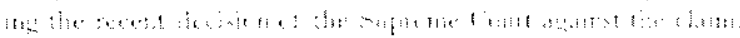

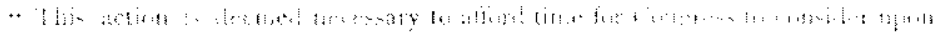

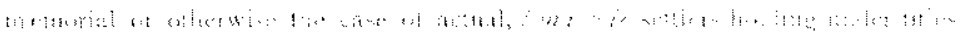

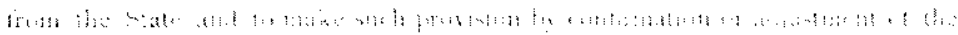

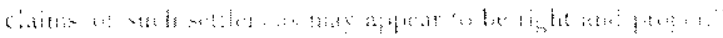

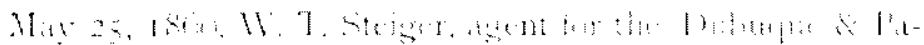

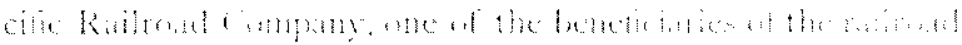

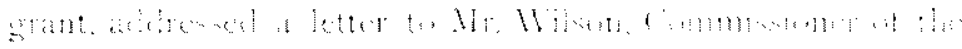

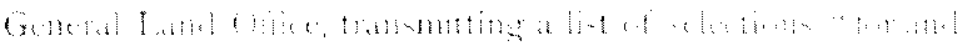

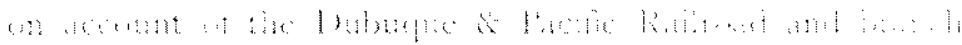

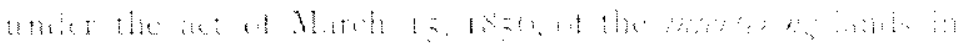

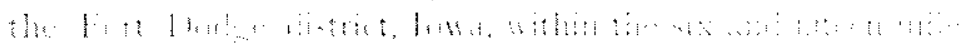

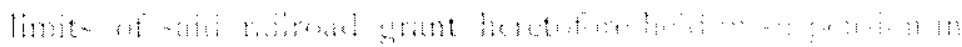

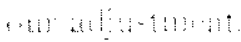

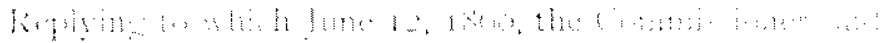

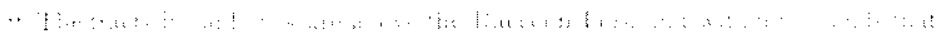

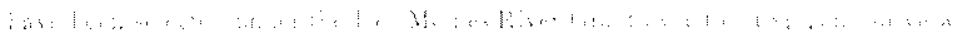

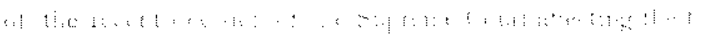

6ron a |

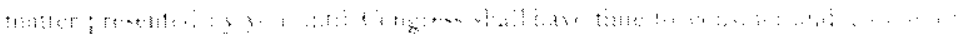
(int at.

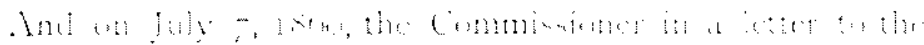

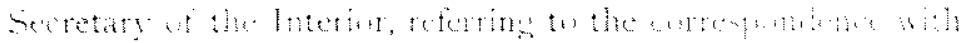
Stuist, silil:

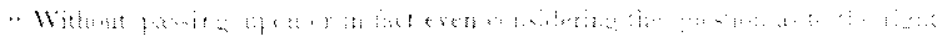

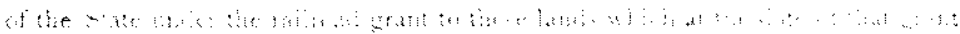
Fed

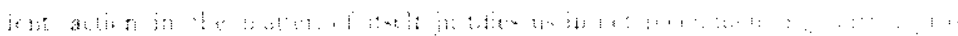
\&

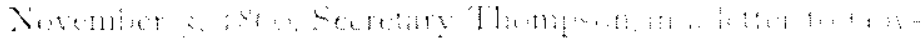

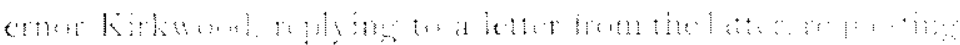

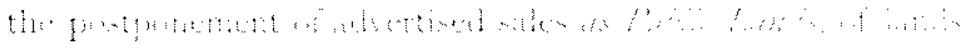

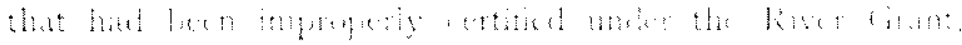

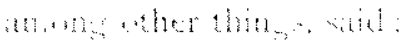

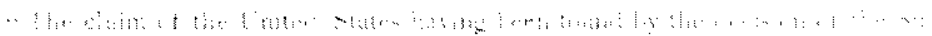

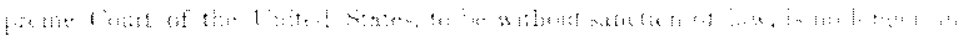

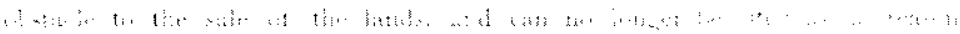

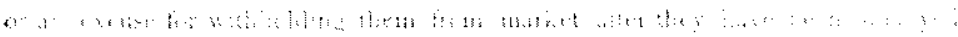




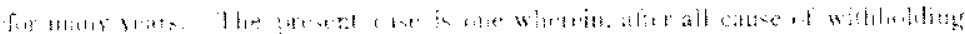

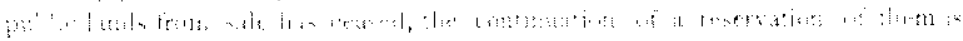

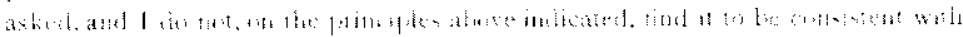

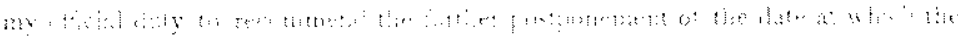

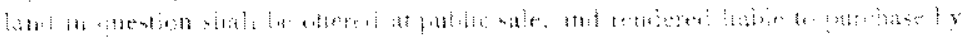

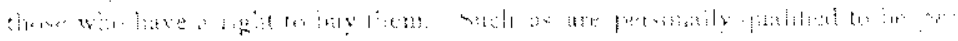

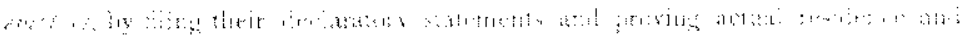

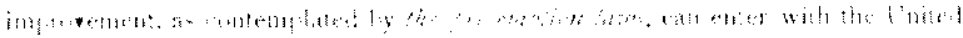

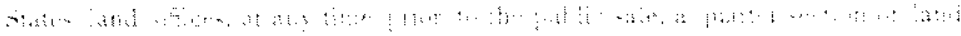

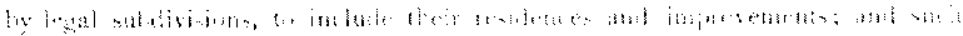

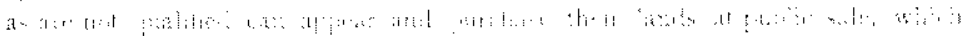

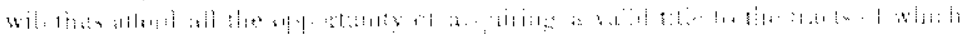
(U)

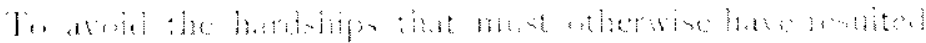

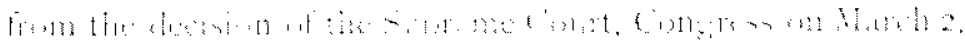

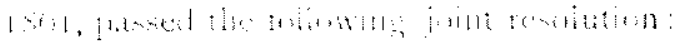

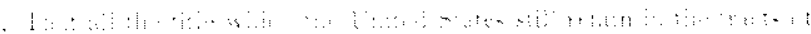
l.,

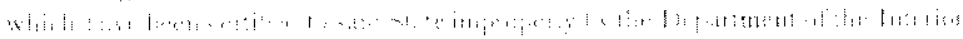
An 1

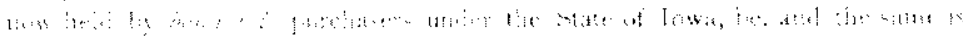

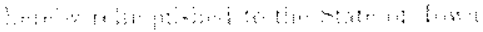

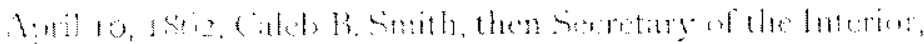

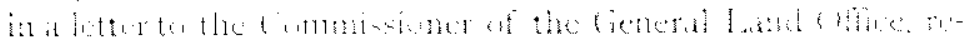

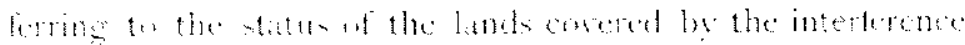

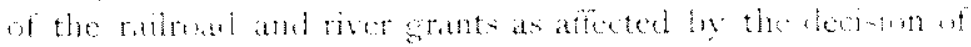

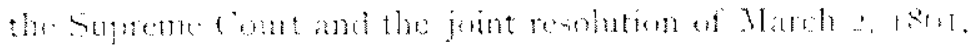
sialel:

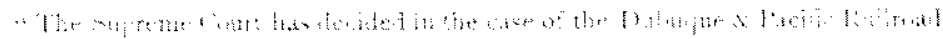

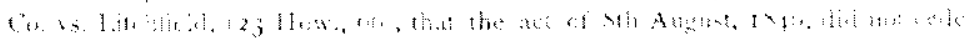

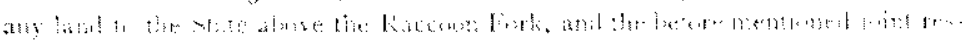

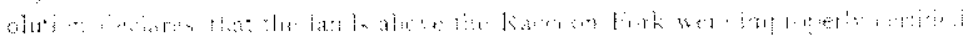

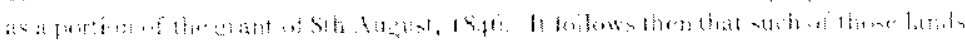

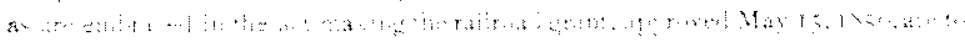

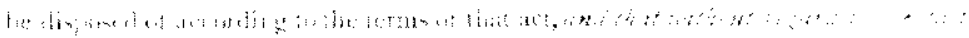

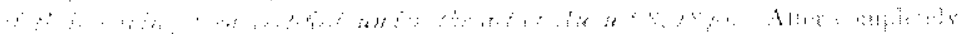

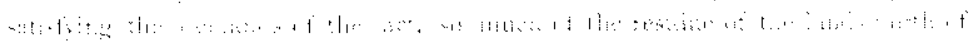

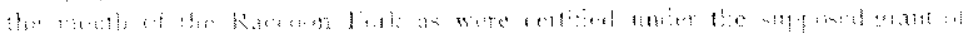

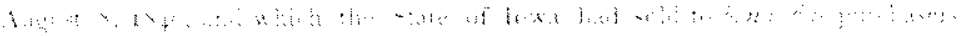

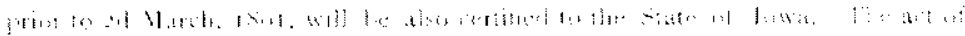

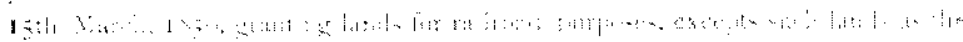

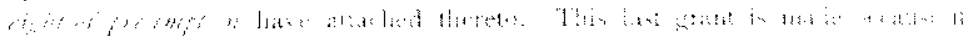

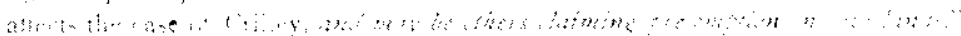


In the language of the Supreme Court of the United States. in Williams vs. Baker, 17 Wall., " to show still further the intention of Congress to make good to the State as far as possible. all that was claimed by her under the original grant," Congress. passed an act approved July I2, I 862, in express terms extend-. ing the grant to the northern boundary of the State, and pro-viding that such lands "be held and applied in accordance with. the provisions of the original grant, except that the consent of Congress is hereby given to the application of a portion thereof to aid in the construction of the Keokuk, Fort Des. Moines \& Minnesota Railroad, in accordance with the provisions of the act of the General Assembly of the State of Iowa, approved March 22, I 858." And providing further, that:

"If any of said lands shall bave been sold or otherwise disposed of by the. United States before the passage of this act, excepting those released by the United States to the grantees of the State of Iowa, under the joint resolution of March 2, I86I, the Secretary of the Interior is hereby directed to set apart an equal amount of lands within said State to be certified in lieu thereof;

And still further providing that:

"If the said State shall have sold and conveyed any portion of the lands lying within the limits of this grant, the title to which has proved invalid, any lands which shall be certified to said State in lieu thereof by virtue of the provisions of this act, shall enure to and be held as a trust fund for the benefit of the person or persons respectively whose titles shall have failed as aforesaid."

April 7,1863 , the lands covered by the interference of the two grants referred to, amounting to 233,453 acres, were certified to the State under the railroad grant, $88,010.66$ acres to. the Dubuque and Sioux City Railroad, 109,756.85 acres to. the Iowa Central Air Line Railroad, and 35,685.49 acres to. the Mississippi and Missouri Railroad.

April 25, 1863, the Commissioner of the General Land Office issued a special certificate which, after reciting the substance of the act of July I2, I 862, concluded as follows :

"Therefore this is to certify that upon the presentation of this paper to any of the land offices in the State of Iowa, accompanied by written authority from the Governor authorizing the party presenting the same as state agent to make indemnity selections under said act, it shall and may be lawful for the Register and Receiver to receive lists of such indemnity selections from such agent, the aggregate of such selections to be restricted to 300,000 acres approximate to the actual 
quantity, to be reduced or increased according to the result of the final adjustment."

During the summer following D. W. Kilbourne, as special agent for the State for that purpose, made the authorized. selections to the amount of $297,603.74$.

In May, I866, the United States and the State of Iowa made. the following adjustment of their land account :

DEBIT.

Acres.

The State of Iowa, with the quantity of indemnity land selected under special certificate dated April $25,1863, \ldots \ldots \ldots \ldots \ldots$

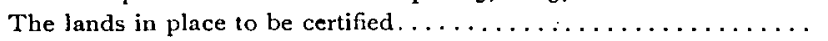

The lands in place confirmed by joint resolution of March 2, 1861 . .

The quantity selected on the east fork of the Des Moines river, and certified to the State under the original lawof August 8, $1846, \ldots$ The excess selected and approved to the State under the 500,000

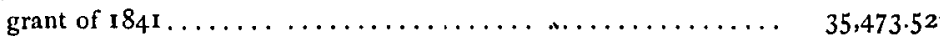
$297,603.74$ $167,109.02$ $44,838.64$ $11,661,80$ $556,686.74$

Remaining indemnity to the State. $\mathbf{1 , 3} \mathbf{1 7 . 3 2}$

CREDIT.

$55^{8,004.06}$

The State of Iowa, with the whole area of the grant above the Rac-

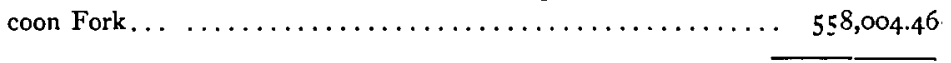

$559,004.06$

After the decision in the Dubuque \& Pacific Railroad Co. vs. Litchfield, holding that the grant did not extend above the Raccoon Fork, the interfering lands were claimed by the Railroad Companies, under the act of May 15, I856; but in the case of Wolcott vs. The Des Moines Company, 5 Wall., $68 \mathrm{I}$, it was held that because of the reservation previously referred to, of March 2, I 849, under the River grant, the proviso in the act of 1856, "that any and all lands heretofore reserved to the United States by any act of Congress or in any. other manner by competent authority for the purpose of aiding in any object of internal improvement or any other object whatsoever, be and the same are hereby reserved to the United States from the operation of this act," had the effect of excepting from the grant the public lands within five miles of the Des Moines. 
river "between the Raccoon Fork so-called and the northern boundary of the State," and that the title to the same passed by the joint resolution of March 26, 1861, and the act of July I2, I 862 .

June 29, I 867, Mr. Wilson, Commissioner of the General Land Office, replying to a letter from Mr. E. C. Litchfield as to the rights of "settlers" on the lands in question under the preemption lazes, in view of the two decisions of the Supreme Court of the United States that have been referred to, said:

"I have come to a different conclusion from what you seem to have reached as to the extent of said decision. The main point ruled by the court was in relation to the specific tract of land within the five mile limit of what is known as the Des Moines River Grant above the Raccoon Fork, under the act of August 8, .1846 , as against the railroad grant under act of 15 th May, 1856 , and recognized title under the first named grant. The question did not come up before the court as to what rights, if any, could have been acquired by actual settlers under the pre-emption law, subsequent to the rejection by said court in 1859 , (23 How., 66) - of the Demoine River claim above the Forks and prior to the passage of the joint resolution of Congress 2nd March, I861, and act of 1 2th July, I 862, in favor of - bona fide purchasers from Iowa. It is true that the court expressed an opinion that under the first named or river grant of 1846 , the odd numbered sections within said limits above the forks were reserved and that title therefore could not pass under the second or railroad grant of 1856 . However this may be, it is held by this office that, after the rejection by the Supreme Court in 1859 of the Des Moines grant as to lands above the Raccoon Fork, and before the preemption of said lands in favor of bona fide purchasers from the State, such reservation did not operate as a bar to the privileged class of persons known to our system as actual settlers under the pre-emption law; and it is not understood rupon what ground a claim under the Des Moines grant can now be set up to the tracts covered by actual settlement by pre-emption, when in the final adjustment of -that grant allowance for the benefit of said improvement claim has been fully given in other lands $b y$ way of indemnity, and accepted by the State accordingly. Your request, therefore, that all pre-emption claims to lands within the limits indicated -be rejected unless they had their inception prior to the original grant of 8 th August, 1846 , is hereby declined."

March 3I, I 868, the State of Iowa granted to the Des -Moines Valley Company, successor to the Keokuk, Fort Des Moines \& Minnesota Company, upon certain conditions not necessary to be mentioned, also with exceptions that need not be specified, all of the lands granted to the State by the act of July I2, I862. By formal conveyances subsequently -executed pursuant to this grant, there were conveyed by the 
State to the Des Moines Valley Company, in round numbers, . 363,000 acres, of which, also in round numbers, 297,000 acres were indemnity lands, certified as before stated, in lieu of lands. that, as was then assumed, had been lost to the River grant by having passed to the State under the Railroad grant. It. having been subsequently held that they were excepted from the Railroad grant by the proviso to which reference has just been made, the State, by the " adjustment," to which reference has also been made, had, as was then understood, at its disposal that much more land than it was entitled to. As was afterward held by the Supreme Court of the United States in Homestead Co. vs. Valley Railroad, I7 Wall, I53, the State acquired title to these indemnity lands by Act of Congress of March 3, I87 I, and not by the "adjustment" of 1866 .

May 9, 1868, Mr. Browning, then Secretary of the Interior, in a communication addressed to Commissioner Wilson, in what is known as the Herbert Battin case, claiming under the pre-emption law under which he had settled upon a tract of river land in October, 1857 , held the claim good as against both the River and the Railroad grants; but in December of the same year, he ordered all pre-emption and homestead entries made against the lands claimed by the Navigation Companÿ, cancelled.

If the narrative of facts contained in this and the preceding paper, simply as a narrative of facts, has been tedious and uninteresting, it will be less so in the light of the relation of the facts stated to the many important and interesting questions to which they gave rise, to the statement of which and when and how they were disposed of, the remainder of this paperwill be given.

The earlier rulings of the land department that the River Grant did not extend above the Raccoon Fork, resulted in the filing, prior to the railroad grant of 1856 , of numerous preemption claims on the land above that point. Among theserulings were that of Acting Commissioner Piper, October 17, I 846 , already referred to, and the decision of Secretary Ewing, April 6, 1850 , in addition to which the lands were pro- 
- claimed for sale by the President of the United States as public lands June 19, I848. After the decision in Dubuque \& Pacific R. R. Co. vs. Litchfield, that the grant only extended to the Raccoon Fork, patents were issued upon some of the pre-emption claims referred to, among others upon one made and proved up by one Hannah Riley. In the case of Wells vs. Riley, involving this Hannah Riley claim, decided by Supreme Court of the United States at its December Term, I 869, not reported, it was held that the pre-emption entry and patent issued on it were void, the reasons for the decision being thus stated in the opinion of the court:

"The tract of land of which the lot in question was a part, had been withdrawn from sale and entry on account of the difference of opinion among the officers of the land department, as to the extent of the original grant by Congress of lands in aid of the improvement of the Des Moines River, from the year 1846 down to the resolution of Congress of March 2, 1861, and the act of July 12, 1862, which act we held (in the Wolcott case) confirmed the title in the Des Moines Company. As the busband of the plaintiff entered upon the lot in 1855 without right, and the possession was continued without right, the permission of the Register to prove up the possession and the improvements, and to make the entry under the preemption law, were acts in violation of law and void, as was also the issue of the patent."

Upon the authority and reasoning of the same rulings as to the extent of the River. Grant, the "interfering " lands were claimed under the railroad grant, but as already shown, the - claim was denied in the Wolcott case, the express condition contained in that act as to reserzed lands being held applicable to the reservation under the Walker decision of 1849 . These decisions holding preemption claims and the claim under the railroad grant void, removed all question as to the title of the United States to the land being perfect at the time of the passage of the joint resolution of I86I, relinquishing to "bona fide purchasers under the State of Iowa," and of the act of I 862 extending the original grant to the north boundary line of the State.

The State having before the decision in the Dubuque \& Pac. R. R. Co. case, sold and conveyed about 272,000 acres of the lands above the Raccoon. Fork on account of the improvement, about 213,000 acres to the Navigation Company, and 
59,000 acres to individual purchasers, the next and the most important of all the questions was, who were the "bona fide purchasers" intended by the joint resolution?

In view of the popular belief that the Navigation Company and its grantees had acquired their title by fraud and substantially without consideration, it was insisted by all opposing claimants that they were not, and that only the individual purchasers were intended. But the popular belief has not been justified in either respect by any of the numerous adjudged cases. The Company obtained in all about 266,000 acres21 3,000 acres above and 53,000 acres below the Raccoon Fork-something over 205,000 acres of which, as has already appeared, were certified to it at the contract price of $\$ 1.25$ per acre, and credited to the State in the adjustment of December 24 , I 856 , at $\$ 256,86 \mathrm{t} .50$. The remaining 6I,000 acres were paid for by the balance of $\$ 40.369 .04$ still due the Company according to the adjustment, $\$ 77,000$ expended by the Company under its contract from December, 1856 , to December, I 857 , as shown by the report of Commissioner Manning of January I, 1858 , and $\$ 20,000$ paid on the final settlement with the State under the joint resolution of March 22, 1858; or at the rate of about $\$ 2.25$ per acre. The amounts stated were all conceded by the State, while the Company claimed to have paid a much larger aggregate amount.

Mr. Justice Nelson, delivering the opining in Wolcott vs. the Des Moines Company, referring to the certificate of Govemor Lowe, of April 28, I 858, said:

"It appears from the certificate of the Governor of Iowa, that the sum of $\$ 33^{2}$,.644 .04 bas already been expended by these defendants, the Navigation Company and its grantees, under their contract."

In Baker vs. Williams, I 7 Wall., I 44 , the court on page 148 , referring to the decision in the Dubuque \& Pacific R. R. Co. case, say:

"It left the State of Iowa, which had made arrangements on the faith of the land certified to it, in an embarrassing condition, and destroyed the title of the Navigation Company to lands of the value of hundreds of thousauds of dollars, which it had received from the State for money, labor and material actually expended and furnished." 
Mr. Justice Miller, delivering the opinion in Bullard. vs: Des. Moines \& Ft. Dodge R. R. Co., I22 U. S., I67, referring to the same matter and to the justice of the relinquishment by Congress to the State by the joint resolution of March 2, 1.86I, of the title to these same lands for the benefit of the Navigation Company and its grantees, on page $I \Rightarrow I$, says :

"The propriety of some action by Congress, and that the demand for it was press. ing, is obvious when we consider that the Des Moines Navigation \& Railroad Company, under the contract with the State, had spent large sums of money beyond what they had received from the State, and beyond the value of the land certified to the State by the Secretary."

In the cases of Welles vs. Riley, Crilley vs. Burrows, involving substantially the same state of facts, Homestead Co. vs. Des Moines Co. et al, and Chapman vs. Woolsey, Io I U. S., 755, Chapman claiming under the River grant and Woolsey under the School Land grant under the erroneous certification to. which reference has been made, the question as to whether or not the Navigation Company and its grantees were bona fide purchasers was expressly put in issue by the pleadings and determined in their favor by the court.

In the last named case it was alleged by Woolsey in his. answer that the Navigation Company falsely and fraudulently pretended and claimed to have kept and performed the conditions of its agreement with the State, and to have expended large sums of money upon the improvement; that the then Governor of Iowa, without authority, and induced thereto by the fraudulent representations of the Navigation Company, conveyed the lands in question to the Company; and further, that the Company, without having paid any consideration therefor, falsely and fraudulently claimed to have been a bonc fide purchaser thereof within the meaning of the joint resolution of $186 \mathrm{I}$. The State of Iowa desiring to have the question of title determined as between the conflicting or contesting, River and School Land grants, under an act of the General Assembly, intervened in the suit and filed its answer denying that the Company was a bona fide purchaser. On the application of the Navigation Company, it was granted leave to intervene and file an argument in the case. It thus appears that 
the issue was distinctly made by the.pleadings, whether or not the Navigation Company and its grantees were bona fide purchasers, on express allegations of all of the particular facts that have ever been suggested even as impeaching the good faith of the Navigation Company and its grantees. The decree of the U.S. Circuit Court, establishing and quieting the title of Chapman, was affirmed by the Supreme Court at the October term, : $879 ; 101$ U. S., 755 . In the opinion, page 765 , it is said:

"The original grant contemplated sales by the State in execution of the trust created, and the bona fide purchasers referred to must have been purchasers at such sales. This heing so, the grant when finally made inured to the benefit of Chapman rather than Woolsey. Neither took title from the State at first, and as the final grant from the United States was in legal effect to Chapman, or his grantees, he has the right to have that fact declared by the judicial decision against Woolsey, who bets up his adverse claim."

And further, page $77 \mathrm{I}$ :

. "After the passage of the joint resolution of March 2, I861, the Commissioner of the General-Land Office called on the Governor of the State for a list of the tracts of land "held by bond fide purchasers of the State of Iowa," on that date. In response to this recpuest the Governor and Land Commissioner of the State, on the 2oth of November, I 862 , furnished the list recuired, and among others included the tracts granted to the Navigation Company on the settlement made with that Company under the joint resolution of March 22, 1858 . This list was filed in the General Land Office December I, i 862."

In Litchfield vs. The County of Webster, IOI U. S. 773, Litchfield being a grantee of the Navigation Company, the court say: "All the lands in this suit had been certified and: Litchfield or those under whom he claims were bona fide purchasers from the State."

Soon after the passage of the joint resolution of $186 \mathrm{I}$, it became a question whether or not these lands thereby became. subject to taxation as against the grantees of the Navigation Company, and in the case of Stryker-one of its granteesvs. Polk County, 22 Iowa, I 3 I, it was held that they did. Referring to the joint resolution it is said :

"If the plaintifi-Stryker-from that time did not have a taxable interest in, this land, we do not well see how he could accuuire it."

And again :

"He held under a deed from the State; the State claimed under the original grant, a list being duly certified, he was a 'bona fide purchaser,' and the title stil. 
retaned by the United States was selinquished to the State for his zuse. . . The joint resolution was intended as a matler of justice and right to secure and quiet bona fide purchasers in their tille, unsettled as they were by the decision of the Supreme Court."

This case was followed by the same court in Litchfield vs. County of Hamilton, 40 Iowa, 66.

In Goodnow vs. Welles, 67 Iowa, 664, in 'which Goodnow was held entitled to recover of Welles, a grantee of the Navigation Company, taxes that had been paid by Goodnow's assignor, claiming title under the railroad grant, for the years I $86 \mathbf{I}-\mathbf{2}-3$, the court say :

"This resolution (joint resolution of I86I) confirmed the grant as to all lands above the Raccoon Fork which were held by bona fide purchasers under the State. The State conveyed the land to defendant's (Welles') grantor in 1858 . Now it is phain that upon the passage and approvat of the joint resolution, the title of the land passed.from the federal government to the grantee of the State. The State bad conveyed the land, though at the time it held no title; but the jount resolution, if it did not directly' vest the title in the State's grantee, did vest it in the State, and that title inured to the benefit of the grantee, who therefore became clothed with title." [Citing Wolcott vs. Des Moines Company, supra.]

This case of Goodnow vs. Welles is only one of not less than a dozen of a similar nature, in which the Supreme Court of Iowa within the last few years has held that the grantees of the Navigation Company were liable to the assignee of the Dubuque \& Sioux City R. R. Co. and the Iowa Homestead Company, to the amount, in the aggregate, of many thousands of dollars, for taxes paid by his assignors on the lands in controversy, during the pendency of the long-continued contest between the respective claimants under the river and ralload grants, on the ground that having afterward been ascertained to be the rightful owners of the land, the law implied a promise of repayment by the succesful to the unsuccessful claimant.

Other cases might be referred to but it is needless, as all are to the same effect.

The debates in Congress on the Joint Resolution have been appealed to on the one hand as showing that the Navigation Company and its grantees were, and on the other hand that they were not contemplated as of the bona fide purchasers provided for. 
In the Senate, Mr. Polk of Missouri having suggested that the resolution as originally offered be so amended as that it should only apply to lands sold by the State to actual settlers, the following running debate occurred:

Mr. GRIMis. - If the Senator will change it so that it shall apply to any purchaser, or any grantee of the State of Iowa, it will be entireiy satisfactory.

Mr. PoLk.-The only objection to that is, that I do not like to give this Con. gressional bounty to land speculators.

Mr. GreEn,-That is just what it is.

Mr. P.JLk.-But to the actual settlers I am willing to give it.

Mr. Grimls. - It would cost a great deal of trouble for us to determine who bappened to be actual settlers at any particular date or at the passage of this reso. lution, or whether it should apply to those who are actual settlers now, or those who were actual settlers at the time they purchased.

Mr. GreEN, - All that can be guarded by saying, 'Any actual, bona fide settler, who, or whose grantor, actually settled on the land.'

MR, Grimes. - The man who, by virtue of your own action, the action of your own officer, went there and obtained the land, if he be not an actual settler, is morally and politically, and in every way just as much entitled to receive justice at the hands of the Senate as the man who is an actual settier. He is a bona fide purchaser. If the Senator will insert the words, : any bona fude purchaser from the State of Iowa,' I shall be satisfied.

MK. POLK: The objection to that is, that it would not shut out the speculators.

Mr. Harlan: So far as this land has been certified to the State, the State has accepted the land, and attempted to apply the proceeds of the grant in the im. provement of the river. A part of this land has been sold by the State directly to actual settlers. A part of the grant has been sold to the gentlemen who were ap. plying their money in. putting in locks and dams, to which reference has been made, and they in turn have sold to other parties. Some of them, perhaps, are not improving the land; but many of them are actual settlers. The purpose of the amendment he proposes is to cut out all those who may have bought those lands of the Des Moines River Improvement Company. That would be unjust to the company and unjust to the purchasers from the company.

Mr. Polk : The view I take of it is this: There is no claim in law or in equity against the United States for the granting of this land; but I am willing the United States should relinquish the title where an actual settler. has bougbt the land, and gone on it; but I am not willing to do that favor to persons who have bought as speculators. Where persons have bought for actual settlement, and have gone on the land, I am willing to vote to relinquish to them, and I am willing to vote for the bill with that amendment. I will offer the amendment, and take the sense of the Senate upon it, to insert the words, "and by the said State sold to actual settlers, and not interfering with public grants."

Mr. CRITTENDen : I will suggest to gentlemen, as there is some difficulty about the provision in reference to actual settlement, to say ' all bona fide purchasers deriving title under the State.' It seems to me that would cover everything. 
Mr. Grimes: That will be entirely satisfactory to me. It seems to me to bejust to all parties. I understand it is satisfactory to the Senator from Missouri.

MR. POLK: I agree to it.

After some further not very material debate, the amendment offered by $\mathrm{Mr}$. Crittenden was agreed to and a vote was taken upon the resolution as amended, with the following result: yeas 30 , nays 7 . Among the yeas were both Grimes and Polk, Grcen voting nay.

In view of the sharply opposing views expressed in the debate, and the comparative unanimity with which the resolution. as amended was adopted, there can be no reasonable doubt that the Crittenden amendment was adopted as a compromise and was intended to leave the question as to who were bona. fide purchasers, should it ever arise, open for determination by the courts.

\section{A FAITHFUL AND ZEALOUS PRIEST.}

The Rev. Father Wm. Emonds, formerly of the Davenport diocese, is now a resident of Tacoma, Washington. He must be quite an aged man, for he was the confidential friend and adviser of Rt. Rev. Matthias Loras, first Catholic bishop of Dubuque, forty years ago. Father Emonds was one of the first priests to visit Des Moines. He came here in ${ }^{8} 54$ and held services in a $\log$ cabin near the river. During the timehe was in Iowa-i $853-90-$ he built some forty-four churches. He secured the first plat of ground in Omaha that was selected. for a Catholic church. He went to Tacoma in 1890 on account of bad health, and has already built two churches on the shores of Puget Sound. Father Emonds never heralds. his own praises, never blows his own horn; on the contrary, he is as modest and unpretentious as he is learned and accomplished. He has been a pillar of strength to his church, a wise and faithful friend to thousands of the poor and needy. Such are the men whom we may believe will receive the plaudit of "Welcome, good and faithful servant."-Iowa State. Register. 
Copyright of Annals of Iowa is the property of State of Iowa, by \& through the State Historical Society of Iowa and its content may not be copied or emailed to multiple sites or posted to a listserv without the copyright holder's express written permission. However, users may print, download, or email articles for individual use. 